\title{
Praktyczne aspekty leczenia żylnej choroby zakrzepowo-zatorowej
}

\section{Venous thromboembolism - practical aspects of treatment}

\author{
Krystyna Zawilska ${ }^{1,2}$, Klaudia Zawilska ${ }^{1,2}$ \\ ${ }^{1}$ Uniwersytet Medyczny im. Karola Marcinkowskiego Marcinkowskiego \\ ${ }^{2}$ Centrum Diagnostyczno-Lecznicze INTERLAB w Poznaniu
}

\begin{abstract}
Streszczenie
Żylna choroba zakrzepowo-zatorowa (VTE) jest czesto wystepujacym groźnym schorzeniem, o zwiększajacej sie zachorowalności w zwiazku ze starzeniem sie spoteczeństw. Leczenie VTE zmienito sie zasadniczo po wprowadzeniu bezpośrednio działajacych doustnych antykoagulantów (DOAC), do których należa inhibitory czynnika krzepnięcia Xa - apiksaban, riwaroksaban, i edoksaban, oraz bezpośredni inhibitor trombiny - dabigatran. W porównaniu z leczeniem standardowym (antykoagulant stosowany parenteralnie $z$ doustnym antykoagulantem $z$ grupy antagonistów witaminy K) DOAC wykazuja podobna skuteczność w zapobieganiu nawrotom VTE, powodujac przy tym mniej powiktań krwotocznych. W artykule określono, którzy pacjenci kwalifikuja sie do leczenia z zastosowaniem DOAC, jaki lek $z$ tej grupy wybrać w określonych sytuacjach klinicznych $i$ jaki jest zalecany optymalny czas leczenia. Omówiono także leczenie powiktan krwotocznych zwiazanych ze stosowaniem DOAC z uwzglednieniem leków swoiście odwracajacych ich dziatanie. $W$ artykule zawarto także aktualne, praktyczne zalecenia dotyczqce leczenia pacjentów $z$ VTE zwiqzana $z$ choroba nowotworowa, pacjentów z matoplytkowościq, niewydolnościa nerek, a także leczenia zakrzepicy żylnej o nietypowej lokalizacji — żyt trzewnych, żyt mózgowych i żyt siatkówki oka.

Słowa kluczowe: żylna choroba zakrzepowo-zatorowa, bezpośrednie doustne antykoagulanty, zakrzepica żylna związana z chorobą nowotworową, małopłytkowość, niewydolność nerek, zakrzepica żył trzewnych, zakrzepica żył mózgowych, niedrożność żył siatkówki oka
\end{abstract}

Hematologia 2016; 7, 3: 231-242

\begin{abstract}
Venous thromboembolism (VTE) is a serious and often fatal medical condition with an increasing incidence due to population aging. The treatment of VTE is undergoing tremendous changes with the introduction of direct oral anticoagulants (DOAC), therefore clinicians need to understand the new treatment paradigms. The DOAC include dabigatran, which inhibits thrombin, and rivaroxaban, apixaban and edoxaban, which inhibit factor Xa. When compared with conventional VTE treatment consisting of a parenteral anticoagulant followed by a vitamin K antagonist, the $D O A C$ were equally effective for prevention of recurrence, but were associated with less bleeding. This paper identifies VTE patients, who are or are not candidates for DOAC, provides guidance on how to choose among DOAC, discusses the optimal treatment duration for VTE and finally, reviews the management of bleeding, including the role of specific reversal agents. Furthemore, this article
\end{abstract}

Adres do korespondencji: Krystyna Zawilska, Uniwersytet Medyczny im. K. Marcinkowskiego; Centrum Diagnostyczno-Lecznicze INTERLAB w Poznaniu, ul. 28 Czerwca 1956 nr 161, 61-505 Poznań, tel. 6183339 49, faks 618331785 , 618527 611, e-mail: k.zawilska@interia.pl 
provides clinical guidance, based on the newest existing guidelines and consensus expert opinion, on the management of patients presenting with cancer-associated VTE, patients with VTE and thrombocytopenia or renal insufficiency, as well as patients with venous thrombosis in unusual sites, such as splanchnic vein thrombosis, cerebral vein thrombosis and retinal vein occlusion.

\section{Key words: venous thromboembolism, direct oral anticoagulants, cancer-associated venous thromboembolism, thrombocytopenia, renal insufficiency, cerebral vein thrombosis, splanchnic vein thrombosis, retinal vein occlusion}

Hematologia 2016; 7, 3: 231-242

\section{Wprowadzenie}

Żylna choroba zakrzepowo-zatorowa (VTE, venous thromboembolism) obejmuje zakrzepicę żył głębokich (DVT, deep vein thrombosis) i zatorowość płucną (PE, pulmonary embolism). Zachorowalność na VTE (pierwsze rozpoznanie i nawroty) waha się między 160 a 183/100 000 osobolat, w wieku poniżej 14 lat wynosi mniej niż 1/100 000 osobolat, zaczyna się zwiększać w wieku około 50 lat, a u osób starszych niz 80 lat dochodzi do 500/100 000 osobolat. Na podstawie badania VITAE (Venous Thrombo-Embolism Impact Assessment Group in Europe) oceniono, że rocznie w krajach Unii Europejskiej może dochodzić do 684000 nowych zachorowań na DVT, 435000 na PE, a liczba zgonów związanych z VTE wynosi 543000 [1]. Jest to 3. co do częstości choroba układu sercowo-naczyniowego, po chorobie niedokrwiennej serca i udarze niedokrwiennym mózgu. Zatorowość płucna jest przyczyną 5-10\% zgonów chorych hospitalizowanych. W badaniach przeprowadzonych w Europie Zachodniej, Stanach Zjednoczonych, Australii i Ameryce Południowej (Argentyna) wykazano, że roczna zachorowalność na VTE waha się między 0,75 a 2,69/1000 osób w ogólnej populacji. Zachorowalność wzrasta $z$ wiekiem i u osób w wieku 70-79 lat wynosi 2-7/1000, a wśród osób w wieku 80 lat i powyżej - 3-12/1000 [2]. W związku ze starzeniem się populacji problem zachorowań na VTE będzie narastał. Na podstawie danych ze Stanów Zjednoczonych i Europy Zachodniej można sądzić, że w Polsce co roku około 56000 osób zapada na objawową DVT, a około 35000 doznaje objawowej PE.

\section{Leczenie żylnej choroby zakrzepowo-zatorowej}

U większości pacjentów w leczeniu DVT oraz PE niewysokiego ryzyka stosuje się leczenie przeciwkrzepliwe [3-6]. Wyróżnia się trzy fazy leczenia VTE: leczenie początkowe (ok. $7 \mathrm{dni}$ ), dłu- goterminowe ( $<3$ miesięcy) i leczenie przewlekłe (> 3 miesięcy). W leczeniu początkowym znajdują zastosowanie następujące leki:

- heparyna drobnocząsteczkowa (LMWH, low molecular weight heparin) podskórnie (s.c., subcutaneous) $\mathrm{w}$ dawce terapeutycznej;

- heparyna niefrakcjonowana (UFH, unfractionated heparin) dożylnie (i.v., intravenous) - bolus $80 \mathrm{jm} . / \mathrm{kg}$, następnie $18 \mathrm{jm} . / \mathrm{kg} / \mathrm{h}$, docelowy czas kaolinowo-kefalinowy (APTT, activated partial thromboplastin time) 2-2,5 $\times$ norma;

- bezpośrednio działające doustne antykoagulanty (DOAC, direct oral anticoagulants), do których należą bezpośrednie inhibitory czynnika krzepnięcia Xa (apiksaban, riwaroksaban i edoksaban) oraz bezpośredni inhibitor trombiny - dabigatran:

- apiksaban $5 \mathrm{mg} 2$ razy/dobę przez tydzień; następnie $2,5 \mathrm{mg} 2 \mathrm{razy} /$ dobę doustnie (p.o., per os), stosować ostrożnie u osób $z$ klirensem kreatyniny $(\mathrm{CrCl}$, creatinine clearance) $15-29 \mathrm{ml} / \mathrm{min}$, nie zaleca się stosowania leku u chorych $\mathrm{z} \mathrm{CrCl}$ poniżej $15 \mathrm{ml} / \mathrm{min}$, u osób poddawanych dializie oraz u pacjentów osób $z$ ciężkimi zaburzeniami czynności wątroby;

- riwaroksaban $15 \mathrm{mg}$ co 12 godzin przez 3 tygodnie następnie $20 \mathrm{mg} 1 \mathrm{raz} /$ dobę p.o., zmniejszenie dawki na $15 \mathrm{mg} 1 \mathrm{raz} /$ /dobę p.o. należy brać pod uwagę jedynie wtedy, gdy ryzyko krwawień przewyższa ryzyko nawrotowej VTE, nie zaleca się stosowania leku u osób z $\mathrm{CrCl}$ poniżej $15 \mathrm{ml} / \mathrm{min}$;

- edoksaban60mg1raz/dobęp.o. (po $\geq 5$ dniach leczenia LMWH albo UFH), $30 \mathrm{mg} 1 \mathrm{raz} /$ /dobę p.o., jeśli $\mathrm{CrCl} 15-50 \mathrm{ml} / \mathrm{min}$, masa ciała (mc.) nie mniejsza niż $60 \mathrm{~kg}$ lub jednoczesne stosowanie inhibitorów glikoproteiny P (cyklosporyna, dronedaron, erytromycyna, ketokonazol);

- dabigatran (po 5-10 dniach leczenia LMWH 
albo UFH) $150 \mathrm{mg}$ co $12 \mathrm{~h}$, pacjenci w wieku co najmniej 80 lat lub jednocześnie przyjmujący werapamil $110 \mathrm{mg}$ co 12 h p.o., u osób z CrCl $30-50 \mathrm{ml} / \mathrm{min}$, osób $z$ zapaleniem błony śluzowej żołądka, zapaleniem błony śluzowej przełyku, refluksem żołądkowo-przełykowym, a także innych osób ze zwiększonym ryzykiem krwawień decyzję o wyborze dawki $300 \mathrm{mg} /$ dobę lub $220 \mathrm{mg} /$ dobę należy podjąć indywidualnie. Nie zaleca się stosowania leku u osób z $\mathrm{CrCl}$ poniżej $30 \mathrm{ml} / \mathrm{min}$;

- fondaparynuks $-5 \mathrm{mg}$ (mc. $<50 \mathrm{~kg}$ ); $7,5 \mathrm{mg}$ (mc. $50-100 \mathrm{~kg}$ ); $10 \mathrm{mg}$ (mc. > $100 \mathrm{~kg}$ ) s.c. $1 \mathrm{raz} /$ dobę. W myśl X wytycznych profilaktyki i leczenia VTE, opracowanych w 2016 roku przez ekspertów ACCP (American College of Chest Physicians) [7] i zaakceptowanych przez Międzynarodowe Towarzystwo Zakrzepicy i Hemostazy (ISTH, International Society on Thrombosis and Haemostasis), DOAC - apiksaban, riwaroksaban, edoksaban i dabigatran - są lekami preferowanymi $\mathrm{w}$ pierwszych 3 miesiącach leczenia VTE u pacjentów bez choroby nowotworowej. Uzasadnieniem tego zalecenia są podobna skuteczność w porównaniu $z$ antagonistami witaminy $\mathrm{K}$ (VKA vitamin $K$ antagonists), obniżone ryzyko poważnych krwawień, w tym krwawień śródczaszkowych i krwotocznych udarów mózgu, oraz większy komfort leczenia $[8,9]$. Bezpośrednio działające doustne antykoagulanty cechują się korzystniejszą farmakodynamiką i farmakokinetyką w porównaniu $z$ VKA - warfaryną czy acenokumarolem. Pełen efekt terapeutyczny DOAC rozpoczyna się już w ciągu $1-4 \mathrm{~h}$, a w przypadku VKA terapeutyczny międzynarodowy współczynnik znormalizowany (INR, international normalized ratio) uzyskuje się zwykle dopiero po 1-3 dniach, stąd konieczność stosowania terapii pomostowej $z$ dodatkowym użyciem heparyny. Bezpośrednio działające doustne antykoagulanty działają krótko, dlatego w przypadku powikłań krwotocznych ich efekt przeciwkrzepliwy bez stosowania dodatkowego leczenia szybko zanika - w ciągu kilku godzin. Bardzo istotne jest też to, że skuteczność DOAC nie zależy od zawartości witaminy $\mathrm{K} \mathrm{w}$ diecie. Podczas leczenia VKA czas utrzymywania się INR w granicach terapeutycznych wynosi zwykle tylko 50-60\% czasu terapii, a DOAC nie wymagają laboratoryjnej kontroli układu krzepnięcia, wymagają natomiast dużej systematyczności zażywania. Ze względu na krótki czas ich działania, opuszczenie nawet jednej dawki powoduje, że skuteczność leczenia się zmniejsza.
Wybór leku przeciwkrzepliwego do leczenia VTE w fazie ostrej powinien się opierać na następujących przesłankach:

- UFH preferowana u pacjentów:

- z PE wysokiego ryzyka lub z proksymalną DVT kwalifikującą się do leczenia inwazyjnego (fibrynolitycznego),

- $z$ dużym zagrożeniem powikłaniami krwotocznymi,

- z niewydolnością nerek $(\mathrm{CrCl}<15 \mathrm{ml} /$ /min),

- ze wskazaniami do przeprowadzenia inwazyjnych zabiegów;

- LMWH preferowane:

- w leczeniu VTE u pacjentów z chorobą nowotworową,

- u kobiet w ciąży i karmiących;

- fondaparynuks preferowany:

- w przypadku podejrzenia lub rozpoznania małopłytkowości poheparynowej (HIT, heparin induced thrombocytopenia),

- w przypadku uczulenia lub nietolerancji heparyn;

- DOAC znajdują szczególne zastosowanie u pacjentów:

- u których nie udaje się utrzymywać INR $\mathrm{w}$ granicach terapeutycznych podczas leczenia za pomocą VKA,

- $z$ trudnościami w oznaczaniu INR, na przykład: ograniczona mobilność, duża odległość od laboratorium, trudny dostęp żylny, brak czasu.

- DOAC nie powinny być stosowane u pacjentów:

- $z$ niewydolnością nerek (riwaroksaban, apiksaban i edoksaban przy $\mathrm{CrCl}<15 \mathrm{ml} /$ $/$ min, dabigatran przy $\mathrm{CrCl}<30 \mathrm{ml} / \mathrm{min}$ ),

- $z$ ciężkim uszkodzeniem wątroby $z$ zaburzeniami krzepnięcia,

- w wieku poniżej 18 lat,

- $\quad$ z zespołem antyfosfolipidowym i przebytac zakrzepicą tętniczą,

- o masie ciała powyżej $120 \mathrm{~kg}$,

- stosujących leki wchodzące w interakcje $z$ DOAC,

- leczonych prasugrelem lub tikagrerolem,

- którzy nie przestrzegają zaleceń lekarskich,

- których nie stać na zakup leku z grupy DOAC, znacznie droższego niż VKA.

Nie przeprowadzono dotąd bezpośredniego porównania (head-to-head) skuteczności i bezpieczeństwa poszczególnych DOAC, ale $z$ analizy ich profilu farmakologicznego oraz badań klinicznych przeprowadzonych w dużych grupach pacjentów 
Tabela 1. Wybór leku z grupy bezpośrednich doustnych antykoagulantów w leczeniu żylnej choroby zakrzepowo-zatorowej zależnie od sytuacji klinicznej

Table 1. Choosing a direct oral anticoagulant in patients with venous thromboembolism in clinical practice

\begin{tabular}{|c|c|c|}
\hline Problem & Lek z wyboru & Uzasadnienie \\
\hline $\begin{array}{l}\text { Uniknięcie konieczności } \\
\text { podawania leku pozajelitowo }\end{array}$ & Riwaroksaban, apiksaban & $\begin{array}{l}\text { Dabigatran i edoksaban wymagają uprzedniego stosowania } \\
\text { heparyny }\end{array}$ \\
\hline $\mathrm{CrCl} 15-50 \mathrm{ml} / \mathrm{min}$ & $\begin{array}{l}\text { Apiksaban, riwaroksaban, } \\
\text { edoksaban }\end{array}$ & $\begin{array}{l}\text { Mniejszy odsetek leku wydalanego przez nerki } \\
\text { w porównaniu z dabigatranem }\end{array}$ \\
\hline $\begin{array}{l}\text { Dolegliwości ze strony przewodu } \\
\text { pokarmowego }\end{array}$ & $\begin{array}{l}\text { Apiksaban, riwaroksaban, } \\
\text { edoksaban }\end{array}$ & Dyspepsja u ok. $10 \%$ pacjentów leczonych dabigatranem \\
\hline $\begin{array}{l}\text { Przebyte krwawienie z przewodu } \\
\text { pokarmowego }\end{array}$ & Apiksaban & $\begin{array}{l}\text { Częstsze krwawienia z przewodu pokarmowego u leczonych } \\
\text { edoksabanem, riwaroksabanem lub dabigatranem niż } \\
\text { u leczonych apiksabanem lub warfaryną }\end{array}$ \\
\hline Choroba niedokrwienna serca & $\begin{array}{l}\text { Apiksaban, riwaroksaban, } \\
\text { edoksaban }\end{array}$ & $\begin{array}{l}\text { Niewielkie zwiększenie zachorowalności na zawał serca } \\
\text { u leczonych dabigatranem }\end{array}$ \\
\hline $\begin{array}{l}\text { Niedokładne przestrzeganie } \\
\text { zaleceń lekarskich }\end{array}$ & Riwaroksaban, edoksaban & $\begin{array}{l}\text { Leki wymagające podawania } 1 \text { ×/d. apiksaban i dabigatran } \\
\text { stosuje się } 2 \times / \text { d. }\end{array}$ \\
\hline
\end{tabular}

wynika, że istnieją między nimi pewne różnice. Warto je uwzględnić w wyborze leku $z$ grupy DOAC (tab. 1).

\section{Leczenie powikłań krwotocznych i leki swoiście odwracające działanie DOAC}

Ze względu na krótki okres półtrwania (5-13h) czas jest najlepszym antidotum w krwawieniach niezagrażających życiu. W przypadku eteksylanu dabigatranu (cząstka lipofilna) można zapobiec jego wchłonięciu $z$ przewodu pokarmowego przez zastosowanie węgla aktywowanego, który jednak musi zostać podany najpóźniej w ciągu $1-2 \mathrm{~h}$ od zażycia leku. Obecnie w sytuacjach krytycznych zaleca się u pacjentów leczonych ksabanami (riwaroksabanem, apiksabanem lub edoksabanem) stosowanie koncentratu czynników rodziny protrombiny (PCC, prothrombin complex concentrate) $\mathrm{w}$ dawce $25 \mathrm{jm} . / \mathrm{kg}$, która może być powtórzona 1-2-krotnie, albo aktywowanego PCC (aPCC, activated PPC) w dawce $50 \mathrm{jm} . / \mathrm{kg}$, maksymalnie $200 \mathrm{jm} . / \mathrm{kg} /$ dobe [10]. Istnieją też doniesienia o dobrych wynikach leczenia krwawień związanych $z$ DOAC rekombinowanym aktywnym czynnikiem krzepnięcia VII (rVIIa). Zalecenia te nie zostały opracowane na podstawie badań klinicznych, wynikają jedynie $z$ badań laboratoryjnych, doniesień kazuistycznych i opinii ekspertów.

W 2016 roku w Unii Europejskiej został zarejestrowany idarucyzumab (preparat Praxbind ${ }^{\circledR}$ ) - lek, który wiąże i neutralizuje dabigatran. Jest to humanizowane mysie monoklonalne przeciwciało skierowane przeciw dabigatranowi (aDabi-Fab), które swoiście wiąże się $z$ dabigatranem wolnym i związanym $z$ trombiną, neutralizując $w$ ten sposób jego aktywność [11]. W razie utrzymywania się krwawienia, albo konieczności przeprowadzenia pilnego zabiegu operacyjnego pacjenci powinni otrzymać 5 g idarucyzumabu i.v. Działaniami niepożądanymi, które wystąpiły u co najmniej $5 \%$ badanych były: hipokaliemia, splątanie, zaparcia, stany gorączkowe, zapalenie płuc. Po leczeniu wytworzyły się przeciwciała przeciw temu lekowi u $4 \%$ badanych $[12,13]$.

Lekiem odwracającym działanie riwaroksabanu, apiksabanu i edoksabanu jest andeksanet alfa - zmodyfikowany rekombinowany czynnik Xa, pozbawiony domeny katalitycznej i możliwości interakcji $z$ innymi czynnikami krzepnięcia, który zachowuje zdolność wiązania się i neutralizowania inhibitorów czynnika Xa. Oprócz ksabanów adneksanet odwraca również działanie LMWH i fondaparynuks. W badaniach III fazy ANNEXA-A (odwracanie działania apiksabanu) i ANNEXA-R (odwracanie działania riwaroksabanu) po zastosowaniu krótkotrwającej infuzji andeksanetu wykazano u zdrowych ochotników szybki spadek aktywności anty-Xa oraz stężenia wolnego apiksabanu lub riwaroksabanu w osoczu. W celu utrzymania tego efektu była konieczna następnie stała infuzja tego leku [14]. Nie stwierdzono istotnych działań niepożądanych u 101 pacjentów, u których zastosowano andeksanet, obecność nieneutralizujących przeciwciał wykryto u $17 \%$ badanych. Nadal trwa badanie ANNEXA-4, jego celem jest ocena skutecz- 
ności i bezpieczeństwa stosowania andeksanetu u pacjentów leczonych inhibitorami czynnika Xa, u których wystąiły powikłania krwotoczne. Lek jest w trakcie przyspieszonej rejestracji w Stanach Zjednoczonych.

Inna substancja - ciraparantag (poprzednie nazwy: aripazine, PER977), która jest małą dodatnio naładowaną cząsteczką, mającą zdolność wiązania się i neutralizowania wszystkich inhibitorów czynnika Xa, z UFH i LMWH włącznie, jest w trakcie badań klinicznych drugiej fazy. Mechanizm działania ciraparantagu polega na blokowaniu interakcji antykoagulantów $z$ antytrombiną albo $z$ aktywnymi czynnikami krzepnięcia. Substancja ta nie wywiera działania prokoagulacyjnego $[15,16]$.

\section{Leczenie VTE związanej}

$\mathrm{z}$ chorobą nowotworową

Zakrzepica żył głębokich kończyn dolnych i PE, zakrzepica żył trzewnych, żył kończyn górnych i innych występuje u 4-20\% chorych na nowotwory złośliwe i jest drugą co do częstości przyczyną zgonu w tej grupie chorych (po samym nowotworze), jej rozpoznanie znacznie pogarsza rokowanie. Zachorowalność na VTE wśród pacjentów $z$ aktywną chorobą nowotworową jest 4-8-krotnie większa niż w populacji ogólnej, większe jest również zagrożenie nawrotem zakrzepicy mimo prawidłowego leczenia $[17,18]$.

W leczeniu wstępnym zakrzepicy DVT u większości chorych na nowotwory zalecane jest stosowanie LMWH s.c. [19-22]:

- dalteparyna w dawce $100 \mathrm{jm} . / \mathrm{kg}$ co $12 \mathrm{~h} \mathrm{lub}$ $200 \mathrm{jm} . / \mathrm{kg}$ co $24 \mathrm{~h}$;

- enoksaparyna w dawce $1 \mathrm{mg} / \mathrm{kg}$ co $12 \mathrm{~h}$ lub postać forte: $1,5 \mathrm{mg} / \mathrm{kg}$ co $24 \mathrm{~h}$;

- nadroparyna w dawce $86 \mathrm{jm} . / \mathrm{kg}=0,1 \mathrm{ml} / 10 \mathrm{~kg}$ masy ciała co $12 \mathrm{~h}$ lub $171 \mathrm{jm} . / \mathrm{kg}=0,1 \mathrm{ml} /$ $/ 10 \mathrm{~kg}$ masy ciała co $24 \mathrm{~h}$.

W przypadku przeciwwskazań do leczenia LMWH rekomenduje się zastosowanie UFH lub fondaparynuksu.

\section{Czy można leczyć VTE, stosując DOAC $\mathrm{u}$ pacjenta $\mathrm{z}$ chorobą nowotworową?}

Bezpośrednio działające doustne antykoagulanty nie zostały dotąd przebadane $\mathrm{w}$ tej grupie chorych, która $z$ jednej strony cechuje się zwiększonym zagrożeniem zakrzepowym, $z$ drugiej zaś zwiększonym ryzykiem powikłań krwotocznych ze względu na często występującą małopłytkowość, krwawienia śluzówkowe lub konieczność wykonywania inwazyjnych zabiegów. U pacjentów chorych na nowotwory często dochodzi do zaburzeń czynności wątroby i nerek czy do wymiotów, a stosowanie $\mathrm{u}$ nich $\mathrm{w}$ terapii przeciwnowotworowej leków metabolizowanych $z$ udziałem CYP3A4 lub glikoproteiny $\mathrm{P}$ może powodować interakcje $z$ DOAC. Do randomizowanych badań klinicznych leczenia VTE $z$ zastosowaniem DOAC obejmujących duże grupy pacjentów włączono tylko $2,5-9,4 \%$ pacjentów $z$ nowotworami. Metaanaliza 6 spośród tych badań, opracowana przez Vedovati i wsp. [23] (dwa badania dotyczące dabigatranu, dwa - riwaroksabanu i po jednym $z$ zastosowaniem apiksabanu lub edoksabanu), których wyniki opublikowano do grudnia 2013 roku, objęła 1132 chorych $z$ VTE i nowotworami złośliwymi. Nawrót VTE stwierdzono u $23(3,9 \%)$ na 595 chorych na nowotwory leczonych DOAC i u $32(6,1 \%)$ na 537 pacjentów leczonych standardowo heparyną $z$ VKA (iloraz szans [OR, odds ratio] 0,63; 95-proc. przedział ufności [CI, confidence interval] 0,37-1,10). Nieznamienna 40-procentowa redukcja częstości nawrotów zakrzepicy u pacjentów leczonych DOAC w porównaniu z chorymi, u których stosowano leczenie standardowe, była obserwowana we wszystkich analizowanych badaniach. Można więc przypuszczać, że skuteczność DOAC w leczeniu VTE związanej $z$ chorobą nowotworową może być porównywalna ze skutecznością LMWH. Podobny był również odsetek poważnych krwawień - odpowiednio: $3,2 \%$ i $4,2 \%$ (OR 0,77; 95\% CI 0,41-1,44), zwraca jednak uwagę około 30-procentowa redukcja wszystkich istotnych klinicznie krwawień w grupie chorych na nowotwory leczonych DOAC. Trudno jednak o wiążące wnioski wynikające $z$ metaanalizy, która objęła stosunkowo małą grupę chorych $z$ nowotworami. W celu wykazania redukcji nawrotu VTE z 5\% do 3\% należałoby przebadać minimum 1500 pacjentów. Brak także danych określających rodzaj, stopień zaawansowania i sposób leczenia nowotworu, kliniczne cechy VTE, a także jakość leczenia VKA, na przykład czas pozostawania INR w granicach terapeutycznych u pacjentów $z$ nowotworami. W grupie kontrolnej u większości chorych stosowano warfarynę, a przecież w 2 randomizowanych badaniach klinicznych wykazano znamiennie większy odsetek nawrotów VTE u pacjentów $z$ chorobą nowotworową leczonych przez pierwszych 6 miesięcy VKA, w porównaniu z leczonymi LMWH [24, 25]. Ocena przydatności DOAC w leczeniu VTE u chorych na nowotwory złośliwe wymaga więc przeprowadzenia odpowiednio zaplanowanych badań klinicznych, między innymi porównania ich skuteczności i bezpieczeństwa $z$ wynikami stosowania LMWH. Według wstępnych 
danych DOAC można stosować u pacjentów $z$ chorobą nowotworową, u których [26]:

- nie wystąpiły krwawienia w poprzedzających 2 miesiącach;

- nie ma guza wewnątrzczaszkowego lub guza w innej lokalizacji, zagrażającej krwawieniami;

- liczba płytek wynosi powyżej $50 \mathrm{G} / 1$, nie zagraża małopłytkowość polekowa;

- $\quad$ APTT i czas protrombinowy są w normie;

- nie ma wykładników uszkodzenia wątroby;

- $\mathrm{CrCl}$ wynosi powyżej $15 \mathrm{ml} / \mathrm{min}$ - można stosować apiksaban, riwaroksaban lub edoksaban; $\mathrm{CrCl}$ jest większy niż $30 \mathrm{ml} / \mathrm{min}$ - można stosować dabigatran;

- nie stosuje się równocześnie leków silnie wpływających na CYP3A4 i/lub glikoproteinę P.

Incydentalna zakrzepica żylna

Incydentalna zakrzepica żylna to VTE przebiegająca skąpoobjawowo w obrazie klinicznym, wykrywana przypadkowo podczas wykonywania diagnostycznych badań obrazowych. Nie jest adekwatne dawniej używane określenie „bezobjawowa VTE”, gdyż u 75\% pacjentów $z$ chorobą nowotworową przypadkowo wykryta PE powodowała objawy kliniczne, najczęściej zmęczenie i duszność, znacznie większe niż w odpowiednio dobranej grupie kontrolnej [27]. Wykazano, że u chorych na raka trzustki incydentalna zakrzepica stanowiła $21,4 \%$ przypadków DVT, 33,3\% PE i 100\% zakrzepicy żył trzewnych [18]. Incydentalną VTE wykrywa się u 4-8\% hospitalizowanych pacjentów z nowotworami i w 1,5-3,4\% badań obrazowych pacjentów ambulatoryjnych, poddawanych diagnostyce $z$ powodu choroby nowotworowej. Skutki zachorowania na incydentalną i objawową VTE są podobne, obie postaci zakrzepicy są niezależnymi czynnikami ryzyka nawrotów VTE i skrócenia czasu życia pacjentów [27]. Zgodnie $z$ wytycznymi opublikowanymi w 2016 roku przez Khorana i wsp. [20] pacjent $z$ incydentalną VTE związaną $z$ chorobą nowotworową powinien otrzymywać przez minimum 6 miesięcy LMWH, podobnie jak pacjenci $z$ objawową zakrzepicą. Wyjątkami są: incydentalna PE ograniczona do tętnic podsegmentowych $\mathrm{i}$ incydentalna zakrzepica żył trzewnych (żyły wrotnej, krezkowej, śledzionowej, nerkowej lub żył narządów rodnych). U chorych $z$ tak zlokalizowaną zakrzepicą decyzję należy podejmować indywidualnie.

Czy należy poszukiwać nowotworu u chorego $\mathrm{z}$ samoistną VTE?

Na podstawie analizy populacji około 60000 pacjentów $z$ DVT/PE zdiagnozowanych w Wielkiej
Brytanii w latach 1981-2000 wykazano, że ryzyko wykrycia nowotworu w ciągu 1-6 miesięcy od zachorowania jest zwiększone 4,2-krotnie (95\% CI 3,9-4,5) w porównaniu z ogólną populacją, a u około $10 \%$ pacjentów $z$ VTE w ciągu 2 lat ujawnia się choroba nowotworowa. Najczęściej diagnozowano raka jajnika, trzustki oraz chłoniaki. Ryzyko było 2-krotnie większe u pacjentów w wieku poniżej 60 lat w porównaniu $z$ podgrupą osób starszych. Po 2 latach od zachorowania ryzyko wykrycia choroby nowotworowej jest takie samo jak w ogólnej populacji [28]. Zgodnie $z$ wytycznymi z 2016 roku $\mathrm{u}$ chorych po przebyciu VTE zaleca się $\mathrm{w}$ diagnostyce przeprowadzanej $z$ podejrzeniem choroby nowotworowej ograniczenie badań do zakresu podstawowego (wywiad, badanie przedmiotowe, podstawowe badania laboratoryjne, radiogram klatki piersiowej) wraz $\mathrm{z}$ skriningiem $\mathrm{w}$ kierunku nowotworów związanych $z$ wiekiem i płcią (rak szyjki macicy, piersi, gruczołu krokowego, jelita grubego) [20]. W wytycznych brytyjskich z 2015 roku wskazuje się natomiast na konieczność przeprowadzenia bardziej szczegółowych badań u pacjentów $z$ obustronną DVT, bardzo dużym stężeniem D-dimeru (> $8000 \mathrm{ng} / \mathrm{ml}$ ) oraz w przypadkach wczesnego nawrotu VTE [29].

\section{Leczenie VTE w przypadkach małopłytkowości}

Leki przeciwkrzepliwe można stosować w pełnych dawkach, jeśli liczba płytek krwi u pacjenta wynosi co najmniej $50 \mathrm{G} / \mathrm{l}$ i nie stwierdza się objawów skazy krwotocznej. W przypadku ostrego epizodu VTE u pacjenta z liczbą płytek krwi poniżej $50 \mathrm{G} / 1$, ale bez objawów skazy krwotocznej jest wskazane toczenie koncentratu krwinek płytkowych w celu utrzymywania liczby płytek krwi co najmniej $50 \mathrm{G} / 1$. Jeśli utrzymanie liczby płytek krwi co najmniej $50 \mathrm{G} / 1$ jest niemożliwe, decyzja o stosowaniu terapeutycznych dawek leku przeciwkrzepliwego lub redukcji tych dawek powinna opierać się na indywidualnej ocenie potencjalnych korzyści i strat związanych $z$ poszczególnymi opcjami terapeutycznymi. Jeśli dzięki przetaczaniu koncentratu krwinek płytkowych udaje się utrzymać liczbę płytek krwi w zakresie 20 -50 G/l, należy zredukować dawkę antykoagulantu do 50\% dawki leczniczej, ale w uzasadnionych przypadkach korzystne może okazać się utrzymanie dawek leczniczych. Przy liczbie płytek poniżej $20 \mathrm{G} / 1$ stosowanie leku przeciwkrzepliwego jest przeciwwskazane, choć ostateczna decyzja musi opierać się na indywidualnej ocenie bilansu ryzyka powikłań zakrzepowych i powikłań krwotocznych. 
Jeśli małopłytkowość objawia się istotną skazą krwotoczną, a ostry epizod DVT kończyn dolnych może zagrażać życiu pacjenta, należy rozważyć implantację usuwalnego filtra do żyły głównej dolnej w celu zapobiegania PE. Z chwilą ustąpienia przeciwwskazań do antykoagulacji należy natychmiast usunąc filtr i włączyć odpowiednie dawki leków przeciwkrzepliwych.

\section{Przezcewnikowa trombektomia i inne metody farmakomechaniczne leczenia zakrzepicy żył głębokich}

Celem tych metod jest szybkie przywrócenie drożności żyły objętej zakrzepem i uniknięcie uszkodzenia zastawek żylnych, zgodnie $z$ tak zwanym open vein concept, w celu zapobiegania rozwojowi zespołu pozakrzepowego [30]. Stosuje się je w przypadkach rozległej zakrzepicy biodrowo-udowej trwającej krócej niż 14 dni u pacjentów z małym ryzykiem krwawień i spodziewanym przeżyciem powyżej roku, a także u pacjentów z DVT kończyn górnych trwającą krócej niż 14 dni lub zagrażającą utratą kończyny. Dobre wyniki daje miejscowe leczenie trombolityczne za pomocą cewnika wprowadzonego do zakrzepu. Leczenie to można łączyć $z$ mechaniczną fragmentacją i aspiracją fragmentów skrzepliny. Po skutecznej trombolizie wszczepia się stent do żyły i stosuje leczenie przeciwkrzepliwe [31,32]. Takie metody jak reolityczna trombektomia (AngioJet) wspomagana ultrasonograficznie albo mechaniczna trombektomia umożliwiają przeprowadzenie leczenia DVT jako terapii jednodniowej. Ogólnoustrojowe leczenie trombolityczne (dawkowanie podobne jak w PE) jest wskazane w przypadku bolesnego obrzęku siniczego (phlegmasia coerulea dolens) jedynie wówczas, gdy nie ma możliwości zastosowania miejscowego wlewu leku trombolitycznego $z$ użyciem metod farmako-mechanicznych.

U chorych $z$ rozpoznaniem DVT jest wskazane stosowanie leczenia uciskowego, początkowo za pomocą opasek uciskowych, a po ustąpieniu obrzę$\mathrm{ku}$ - pończoch albo podkolanówek elastycznych II klasy ucisku przez co najmniej 2 lata.

\section{Leczenie VTE o nietypowej lokalizacji [33]}

Wykazano, że w przypadku zakrzepicy żył trzewnych (SVT, splanchnic veins thrombosis) leczenie przeciwkrzepliwe przedłuża czas życia, zmniejsza częstość nawrotów, przyczynia się do rekanalizacji żył, zwiększa jednak ryzyko krwawień $z$ przewodu pokarmowego (badania obserwacyjne). Leczenie przeciwkrzepliwe powinno być brane pod uwagę u wszystkich pacjentów z objawową SVT bez aktywnego krwawienia albo po usunięciu źródła krwawienia i stabilizacji stanu pacjenta. U chorych $z$ incydentalną SVT decyzję podejmuje się indywidualnie, biorąc pod uwagę ryzyko nawrotu (stany prozakrzepowe) i ryzyko powikłań krwotocznych. U pacjentów $z$ SVT związaną $z$ chorobą nowotworową (20-27\% chorych na SVT) oraz u osób z dużym ryzykiem krwawień (marskość wątroby, żylaki przełyku, małopłytkowość) poleca się stosowanie LMWH, pozostałym stabilnie klinicznie chorym można podawać warfarynę albo acenokumarol. U osób $z$ bardzo dużym ryzykiem krwawienia albo wymagających inwazyjnych procedur zaleca się stosowanie UFH. U wszystkich pacjentów $z$ SVT i marskością wątroby wskazana jest rutynowa diagnostyka w kierunku żylaków przełyku i ich leczenie. W czasie terapii należy stosować LMWH w wysokości pół dawki terapeutycznej albo w dawce profilaktycznej w zależności od liczby płytek, a LMWH w dawce terapeutycznej - dopiero po zakończeniu leczenia żylaków przełyku. Nie ma danych na temat stosowania DOAC. Leczenie przeciwkrzepliwe powinno trwać minimum 3 miesiące $u$ wszystkich chorych z SVT. U pacjentów $z$ SVT i przejściowym czynnikiem ryzyka (operacja, zakażenie) terapię można zakończyć po 3 miesiącach. Pozostali pacjenci wymagają leczenia przewlekłego $z$ okresową kontrolą ryzyka nawrotu i ryzyka krwawień. Terapia fibrynolityczna jest wskazana w wybranych przypadkach zakrzepicy żył krezkowych $z$ grożącą martwicą jelit lub gdy stan kliniczny się pogarsza mimo prawidłowego leczenia przeciwkrzepliwego.

Zakrzepica żył mózgowych (CVT, cerebral vein thrombosis) najczęściej występuje u osób młodych, w tym w 75\% u kobiet. Czynnikami ryzyka są: doustna antykoncepcja, ciąża, urazy głowy, zabiegi neurochirurgiczne, nakłucie lędźwiowe, zakażenia (zapalenie uszu, zapalenie wyrostka sutkowatego, zapalenie opon mózgowych). Zakrzepicy żył mózgowych często towarzyszy krwawienie śródmózgowe (ok. 40\%). Wszyscy pacjenci z CVT wymagają leczenia przeciwkrzepliwego, a współistniejące krwawienie śródmózgowe nie jest przeciwwskazaniem do jego stosowania. W pierwszych dniach należy stosować LMWH albo UFH, a przejście na VKA jest możliwe dopiero po ustabilizowaniu stanu klinicznego i uzyskaniu poprawy w zakresie świadomości i innych odchyleń neurologicznych oraz w badaniach obrazowych. Heparyna niefrakcjonowana jest preferowana $\mathrm{u}$ chorych niestabilnych klinicznie, mogących wymagać inwazyjnych procedur, na przykład nakłucia lędźwiowego lub dekompresyjnej hemikraniotomii. Miejscowe albo 
ogólnoustrojowe leczenie fibrynolityczne zaleca się w wybranych przypadkach ciężkiego stanu klinicznego, między innymi śpiączki, a także gdy stan kliniczny się pogarsza mimo prawidłowego leczenia przeciwkrzepliwego, po wykluczeniu innych przyczyn. Dotyczy to pacjentów, u których nie ma dużego ogniska krwotocznego i którym nie zagraża wgłobienie. Leczenie przeciwkrzepliwe powinno być stosowane przez minimum 3 miesiące u wszystkich pacjentów z CVT, a u chorych z CVT i z przejściowym czynnikiem ryzyka (np. doustne środki antykoncepcyjne) można je zakończyć po tym czasie. Pacjenci bez wykrywalnych czynników ryzyka CVT wymagają leczenia przez 6-12 miesięcy. Chorzy z utrzymującymi się czynnikami ryzyka zakrzepowego, między innymi $z$ ciężką trombofilią (niedobór antytrombiny, białka C lub S, zespół antyfosfolipidowy, homozygotyczna mutacja genu czynnika V lub protrombiny, podwójne heterozygoty) oraz pacjenci $z$ nawrotową CVT wymagają leczenia przewlekłego.

Niedrożność żył siatkówki (RVO, retinal vein occlusion) jest drugą co do częstości po retinopatii cukrzycowej chorobą siatkówki prowadzącą do utraty wzroku. Czynniki ryzyka to: wiek powyżej 65 lat, nadciśnienie tętnicze, miażdżyca, hiperlipidemia, cukrzyca, otyłość, wzmożona lepkość krwi, wrodzone i nabyte zaburzenia układu krzepnięcia, stany zapalne naczyń, choroby autoimmunologiczne, palenie tytoniu, stosowanie doustnych leków antykoncepcyjnych. Przyczynami powstania zakrzepu w żyłach siatkówki są najczęściej zmiany miażdżycowe w tętnicy środkowej siatkówki z uciskiem na ściany żył siatkówki, ucisk żylny (jaskra, zapalny obrzęk nerwu wzrokowego, choroby oczodołu), zaburzenia hemodynamiczne i stany zapalne naczyń siatkówki. Na powstanie RVO wpływają najczęściej zmiany miejscowe na dnie oka albo zmiany miażdżycowe. Terapeutyczna rola leków przeciwkrzepliwych nie została zbadana. Częściej stosuje się leki przeciwpłytkowe (kwas acetylosalicylowy [ASA, acetylsalicylic acid], klopidogrel), których rola też nie jest znana. Niektórzy eksperci sugerują leczenie przeciwkrzepliwe u pacjentów $z$ ciężką trombofilią. Jeśli włącza się leczenie przeciwkrzepliwe, to w ostrej fazie RVO lekiem $Z$ wyboru jest LMWH w dawce terapeutycznej, czas leczenia trwa 1-3 miesięcy. Leczenie fibrynolityczne może być stosowane tylko w wybranych przypadkach, na przykład w RVO $z$ całkowitą utratą wzroku. U pacjentów, u których istnieją czynniki ryzyka miażdżycy, wskazane jest przewlekłe stosowanie ASA.
Leczenie fibrynolityczne stosowane

w PE wysokiego ryzyka

i w wybranych przypadkach

rozległej proksymalnej DVT [3-5]

1) Streptokinaza:

- schemat przyspieszony (preferowany): $1,5 \mathrm{mln}$ jm. i.v. w ciagu $2 \mathrm{~h}$;

- schemat standardowy: $250000 \mathrm{jm}$. i.v. w ciągu $30 \mathrm{~min}$, następnie $100000 \mathrm{jm} . / \mathrm{h}$ przez $12-24 \mathrm{~h}$;

2) Rekombinowane tkankowe aktywatory plazminogenu (rtPA, recombinant tissue plasminogen activator) (alteplaza):

- schemat standardowy: $100 \mathrm{mg} i . v$. w ciągu $2 \mathrm{~h}$;

- schemat przyspieszony: $0,6 \mathrm{mg} / \mathrm{kg}$ (maks. $50 \mathrm{mg}$ ) i.v. w ciągu $15 \mathrm{~min}$.

Nowe leki fibrynolityczne zarejestrowane w Unii Europejskiej do leczenia PE to reteplaza dawce $0,25-0,75 \mathrm{j}$./h i tenekteplaza w dawce $0,25-0,5 \mathrm{mg} / \mathrm{h}$. Podawanie UFH można rozpocząc przed wdrożeniem leczenia fibrynolitycznego (80 jm./kg i.v.) albo jednocześnie $z$ nim; u chorych otrzymujących ciągły wlew UFH $(18 \mathrm{jm} . / \mathrm{kg} / \mathrm{h}$ $z$ monitorowaniem APTT; wartość docelowa: 1,5-2,5 wartości kontrolnej) można go wstrzymać podczas wlewu leku trombolitycznego albo kontynuować według dotychczasowego schematu (niektórzy autorzy zalecają wstrzymanie wlewu UFH podczas podawania alteplazy). Po zakończeniu leczenia fibrynolitycznego i uzyskaniu stabilnego stanu klinicznego pacjenta można rozpocząć stosowanie VKA według tych samych zasad, jak w leczeniu DVT. W PE wysokiego ryzyka należy ponadto włączyć leczenie objawowe hipoksji, hipotensji lub wstrząsu (tlen, katecholaminy, u chorych $z$ małym rzutem serca - dobutamina i dopamina, nie zaleca się intensywnej płynoterapii).

W przypadku przeciwwskazań do leczenia fibrynolitycznego należy wziąć pod uwagę możliwość wykonania chirurgicznej embolektomii płucnej albo usunięcia zakrzepu przez cewnik. Embolektomię płucną można też rozważyć u chorych $z$ PE i ruchomą skrzepliną w jamach prawego serca.

Chorzy z PE niskiego i pośredniego-niskiego ryzyka mogą dość szybko zostać wypisani ze szpitala albo można ich leczyć przeciwkrzepliwie $\mathrm{w}$ warunkach ambulatoryjnych. Minimalne warunki to: stabilny stan kliniczny pacjenta i prawidłowe podstawowe parametry życiowe, małe ryzyko krwawienia, stężenie kreatyniny w surowicy poniżej $150 \mu \mathrm{mol} / 1$ lub $\mathrm{CrCl}$ powyżej $60 \mathrm{ml} / \mathrm{min}$, zapewniony system podawania leków przeciw- 
krzepliwych i fachowa obserwacja przez dobrze wyszkoloną pielęgniarkę lub lekarza pod kątem powikłań krwotocznych i skuteczności leczenia przeciwkrzepliwego oraz nawrotu VTE. Obecność balotującej skrzepliny w żyle biodrowej jest przeciwwskazaniem do leczenia $\mathrm{w}$ warunkach ambulatoryjnych przez pierwsze $2-3$ dni, ale nie wymaga unieruchomienia w łóżku.

Chorych pośredniego-wysokiego ryzyka powinno się leczyć tak samo jak pacjentów niskiego ryzyka, ale w warunkach szpitalnych. Taka kwalifikacja nakazuje ścisłe monitorowanie w celu wykrycia dekompensacji hemodynamicznej, która jest wskazaniem do terapii reperfuzyjnej [34].

Według aktualnych zaleceń American College of Chest Physicians (ACCP) u chorych $z$ PE ograniczoną do tętnic podsegmentowych, bez współistniejącej DVT, $z$ małym ryzykiem nawrotu VTE nie jest wymagane leczenie przeciwkrzepliwe, wskazana jest natomiast aktywna obserwacja i powtórzenie badania ultrasonograficznego (USG) żył głębokich. $\mathrm{Za}$ takim postępowaniem przemawia zwiększone ryzyko powikłań krwotocznych u pacjenta, przeciw takim działaniom przemawiają zaś: wspólistniejąca choroba nowotworowa, hospitalizacja lub unieruchomienie, samoistna postać zakrzepicy, a także obecność objawów klinicznych i mała rezerwa sercowo-naczyniowa. Decyzję o wyborze leczenia w PE obejmującej tylko tętnice podsegmentowe należy przedyskutować $z$ pacjentem [7].

\section{Wskazania do umieszczenia filtru \\ w żyle głównej dolnej}

Umieszczenie filtru w żyle głównej dolnej (preferowany filtr czasowy) u pacjentów ze świeżą proksymalną DVT jest konieczne w następujących przypadkach [3-5]:

- bezwzględne przeciwwskazanie do leczenia przeciwkrzepliwego;

- brak skuteczności leczenia przeciwkrzepliwego (nawrót PE lub znaczne powiększenie się zakrzepu mimo właściwego leczenia);

- ciężka niewydolność serca lub dysfunkcja płuc zagrażająca zgonem w razie nawrotu $\mathrm{PE}$;

- stan po przebyciu PE z zakrzepowo-zatorowym nadciśnieniem płucnym.

\section{Czas trwania leczenia VTE}

- leczenie dlugoterminowe $(<3$ miesięcy)

i leczenie przewlekłe

Minimalny czas leczenia to 3 miesiące. Według aktualnych zaleceń ACCP u pacjentów po pierwszym epizodzie niesprowokowanej proksymalnej DVT kończyn dolnych lub PE, u których ryzyko powikłań krwotocznych jest małe albo umiarkowane, zaleca się leczenie przewlekłe (bezterminowe). Jeśli ryzyko powikłań krwotocznych jest duże, należe natomiast ograniczyć czas trwania leczenia do 3 miesięcy. U wszystkich chorych należy okresowo (np. co rok) oceniać wskazania do kontynuacji leczenia przeciwzakrzepowego i ustalać dalsze postępowanie indywidualnie, po uzgodnieniu $z$ pacjentem, biorąc pod uwage ryzyko nawrotu oraz ryzyko powikłań krwotocznych [7]. Leczenie przewlekłe stosuje się zwłaszcza u osób ze współistniejącą chorobą nowotworową, w której ryzyko nawrotu jest znacznie zwiększone, lub $z$ utrzymującymi się innymi czynnikami zagrożenia zakrzepowego, a także w przypadku zakrzepicy związanej $z$ obecnością cewnika - do czasu usunięcia cewnika. Czynniki ryzyka krwawienia przy stosowaniu leczenia przeciwkrzepliwego są następujące: wiek powyżej 75 lat, przebyte krwawienie, nowotwór złośliwy, niewydolność nerek, niewydolność wątroby, małopłytkowość, przebyty udar mózgu, cukrzyca, niedokrwistość, leczenie przeciwpłytkowe, zła kontrola leczenia przeciwkrzepliwego, inne choroby wspólistniejące i zmniejszona sprawność fizyczna, niedawno przebyty zabieg operacyjny, częste upadki, nadużywanie alkoholu. Ryzyko krwawienia będzie zależało od: stopnia nasilenia czynnika ryzyka (np. umiejscowienie i liczba przerzutów nowotworowych, liczba płytek krwi), związku czasowego (np. czas od zabiegu operacyjnego lub przebytego krwawienia) i skuteczności leczenia poprzedniej przyczyny krwawienia (np. $z$ górnego odcinka przewodu pokarmowego). Jeśli ryzyko powikłań krwotocznych jest małe (0 czynników ryzyka) lub umiarkowane (1 czynnik), należy już po pierwszym epizodzie samoistnej proksymalnej DVT i/lub PE stosować stałe leczenie przeciwzakrzepowe. Jeśli ryzyko powikłań krwotocznych jest duże ( $\geq 2$ czynniki ryzyka), leczenie można skrócić do 3 miesięcy. Po wystąpieniu 2 incydentów samoistnej VTE jest wskazane stałe leczenie przeciwzakrzepowe.

\section{Leki stosowane}

w przewlekłym leczeniu VTE

1) LMWH s.c. - w monoterapii przez 6 miesięcy preferowana u pacjentów $z$ VTE $\mathrm{w}$ przebiegu choroby nowotworowej - przez miesiąc w $100 \%$, a następnie w około $75 \%$ dawki terapeutycznej, oraz u kobiet w ciąży.

2) Antagoniści witaminy $\mathrm{K}$ (warfaryna, acenokumarol) p.o. - dawkowanie według INR (docelowy INR 2-3). W początkowym okresie leczenia wskazane jednoczesne stosowanie 
z LMWH albo UFH przez co najmniej 5 dni, do czasu utrzymywania się INR nie mniejszego niż 2,0 przez dłużej niż $24 \mathrm{~h}$.

3) Riwaroksaban $-20 \mathrm{mg} \mathrm{raz/dobę} \mathrm{p.o.}$

4) Dabigatran $-150 \mathrm{mg}$ co $12 \mathrm{~h}$, pacjenci w wieku co najmniej 80 lat, pacjenci jednocześnie przyjmujący werapamil - $110 \mathrm{mg}$ co $12 \mathrm{~h}$ p.o.

5) Apiksaban - 2,5 mg 2 razy/dobę p.o.

6) Kwas acetylosalicylowy $-100 \mathrm{mg} \mathrm{raz} /$ dobę p.o.

7) Sulodeksyd - 250 SLU 2 razy/dobę p.o.

Nowością są zalecenia dotyczące postępowania u pacjentów, u których przerywa się leczenie przeciwkrzepliwe trwające 3-18 miesięcy po pierwszym epizodzie samoistnej VTE. Randomizowane badania kliniczne wykazały, że ASA w małej dawce $(100 \mathrm{mg} / \mathrm{d}$.) zmniejsza o około $30 \%$ $\mathrm{u}$ takich chorych ryzyko nawrotu VTE, bez istotnego zwiększenia częstości powikłań krwotocznych [35]. Jeśli nie ma przeciwwskazań do stosowania ASA, lek ten jest wartościową opcją terapeutyczną u pacjentów po zakończeniu standardowego leczenia pierwszego epizodu VTE. Opcja ta może być szczególnie przydatna u osób $z$ dużym ryzykiem powikłań krwotocznych lub rezygnujących $z$ powodu uciążliwości $z$ przewlekłego stosowania leków bardziej skutecznych — VKA lub DOAC [7]. W niedawno opublikowanym badaniu Sulodexide in Secondary Prevention of Recurrent Deep Vein Thrombosis (SURVET) wykazano, że doustne stosowanie sulodeksydu w dawce 500 SLU/dobę łącznie $z$ kompresjoterapią przez 2 lata (po zakończeniu standardowego leczenia przeciwkrzepliwego) około 2-krotnie zmniejsza ryzyko nawrotu VTE bez zwiększenia ryzyka powikłań krwotocznych. Lek ten mógłby być stosowany u pacjentów $z$ umiarkowanym lub małym zagrożeniem nawrotem VTE, chorych niewyrażających zgody na dalsze stosowanie innych leków przeciwkrzepliwych, a także u osób w podeszłym wieku ze zwiększonym ryzykiem powikłań krwotocznych [36].

\section{Leczenie nawrotu VTE podczas}

leczenia przeciwkrzepliwego

Nawrót zakrzepicy podczas leczenia przeciwkrzepliwego rzadko się zdarza, ale jest powikłaniem mogącym zagrażać życiu chorego. Jedną z przyczyn nawrotu jest zbyt mała intensywność antykoagulacji, najczęściej wynikająca $z$ zaniedbań ze strony pacjenta (nieregularne stosowanie mających krótki okres półtrwania DOAC albo utrzymywanie INR poniżej 2,0 podczas leczenia doustnymi antykoagulantami $z$ grupy VKA). Inną przyczyną może być nadkrzepliwość, związana $z$ istniejącym wyjątkowo silnym czynnikiem ryzyka zakrzepowego, dla której konwencjonalne leczenie przeciwkrzepliwe nie jest wystarczająco skuteczne. Modelowym czynnikiem zwiększającym ryzyko nawrotu VTE jest aktywna choroba nowotworowa. Dlatego wystąpienie nawrotu u pacjenta prawidłowo leczonego przeciwkrzepliwie stanowi wskazanie do poszukiwania utajonej choroby nowotworowej. Do innych przyczyn nawrotu podczas leczenia przeciwkrzepliwego należą: obecność przeciwciał antyfosfolipidowych, zespół mieloproliferacyjny, nocna napadowa hemoglobinuria, HIT z zakrzepicą, dysfibrynogenemia, lub istnienie anomalii anatomicznych, których przykładem jest zespół May-Thurnera, zespół Pageta i Schröttera lub zespół górnego otworu klatki piersiowej.

Za czynniki ryzyka nawrotu VTE uznaje się:

- liczbę przebytych incydentów VTE (po każdym incydencie zwiększa się ryzyko nawrotu);

- lokalizacja zakrzepicy — PE > DVT proksymalna > DVT dystalna;

- pleć męska;

- obecność rezydualnej skrzepliny;

- stężenie D-dimeru po zaprzestaniu leczenia przeciwkrzepliwego ( $>$ wartości: wiek $\times 10 \mathrm{ng} /$ $/ \mathrm{ml}$;

- choroba nowotworowa;

- trombofilia.

Jeśli nawrót wystąpił przy INR poniżej 2,0, poleca się zastosowanie terapeutycznej dawki LMWH, a następnie przy ponownym włączeniu VKA - częste monitorowanie INR, najlepiej przy użyciu aparatu monitorującego INR w domu pacjenta (np. Coagu-Check XS) i komputerowego programu samokontroli INR. Alternatywną możliwością jest przewlekłe leczenie przeciwkrzepliwe za pomocą DOAC. U chorych, u których nawrót nastąpił przy INR powyżej 2,0, zaleca się podanie małej dawki witaminy $\mathrm{K}(1-2 \mathrm{mg})$ i włączenie LMWH w dawce terapeutycznej. Nawrót, który wystąpił u chorego $z$ VTE podczas stosowania LMWH $\mathrm{w}$ dawce terapeutycznej, wymaga zwiększenia tej dawki o 20-25\%, najlepiej pod kontrolą aktywności anty-Xa. Inne opcje terapeutyczne polecane przez ekspertów to dołączenie ASA do LMWH albo zastosowanie fondaparynuksu. Jeśli do nawrotu doszło podczas stosowania DOAC, zaleca się przejście na LMWH w pełnej dawce terapeutycznej, a następnie włączenie VKA $z$ docelowym INR 2,0-3,0 [37].

\section{Zespół pozakrzepowy}

Ryzyko rozwoju zespołu pozakrzepowego w ciągu 2, 5 i 8 lat po wystąpieniu DVT wynosi odpowiednio: $23 \%, 28 \%$ i $29 \%$. Stosowanie pończoch 
albo podkolanówek elastycznych przez minimum 2 lata zapobiega temu powikłaniu. Sugeruje się nawet dłuższe ich stosowanie, jeśli wystąił zespół pozakrzepowy, a chory uważa to za pomocne. Postęp metod endowaskularnych umożliwia leczenie ciężkich postaci zespolu pozakrzepowego przez rewaskularyzację żył w odcinku biodrowo-udowym $\mathrm{z}$ wszczepieniem stentu.

\section{Dystalna DVT}

Dystalna DVT wymaga leczenia przeciwkrzepliwego takiego samego jak zakrzepica proksymalna, jeśli powoduje istotne objawy kliniczne albo zagraża rozwojem zmian zakrzepowych do żył podkolanowych (15\% przypadków). U pozostałych chorych można się ograniczyć do leczenia objawowego i kontroli USG żył co 2-3 dni przez 2 tygodnie. Czynnikami ryzyka narastania zakrzepu, wymagającego włączenia leczenia przeciwkrzepliwego, są: wysokie stężenie dimeru D, długość skrzeplin ponad $5 \mathrm{~cm}$, skrzepliny ponad $7 \mathrm{~mm}$ w kilku żyłach, skrzepliny w pobliżu żył proksymalnych, samoistna postać zakrzepicy, aktywna choroba nowotworowa, VTE w wywiadzie, hospitalizacja. Czynnikami ryzyka progresji są: wysokie stężenie D-dimeru, długość skrzeplin powyżej $5 \mathrm{~cm}$, skrzepliny powyżej $7 \mathrm{~mm}$ w kilku żyłach, skrzepliny w pobliżu żył proksymalnych, samoistna postać zakrzepicy, aktywna choroba nowotworowa, VTE w wywiadzie i hospitalizacja [7].

\section{Piśmiennictwo}

1. Cohen A.T., Agnelli G., Anderson F.A. i wsp. Venous thromboembolism (VTE) in Europe. The number of VTE events and associated morbidity and mortality. Thromb. Haemost. 2007; 98: 756764.

2. ISTH Steering Committee for World Thrombosis Day. Thrombosis: a major contributor to the global disease burden. J. Thromb. Haemost. 2014; 12: 1580-1590.

3. Kearon C., Akl EA., Comerota AJ. i wsp. Antithrombotic therapy for VTE disease. Antithrombotic therapy and prevention of thrombosis. 9th ed. American College of Chest Physicians evidence-based clinical practice guidelines. CHEST 2012; 141 (supl.): e419S-e494.

4. Polskie wytyczne profilaktyki i leczenia żylnej choroby zakrzepowo-zatorowej: aktualizacja 2012. Med. Prakt. 2012. Wyd. specj.: Żylna choroba zakrzepowo-zatorowa.

5. Zawilska K., Bała M.M., Błędowski P. i wsp.; Working Group for the Anticoagulation and Thrombolytic ACCP Conference. Polish guidelines for the prevention and treatment of venous thromboembolism. 2012 update. Pol. Arch. Med. Wewn. 2012; 122 (supl. 2): 3-74.

6. Zawilska K. Żylna choroba zakrzepowo-zatorowa. W: Robak T., Warzocha K. (red.). Hematologia. Via Medica, Gdańsk 2016: 507-521.

7. Kearon C., Akl E.A., Ornelas J. i wsp. Antithrombotic therapy for VTE disease: CHEST guideline and expert panel report. Chest 2016; 149: 315-352.
8. van der Hulle T., Kooiman J., den Exter P.L. i wsp. Effectiveness and safety of novel oral anticoagulants as compared with vitamin $\mathrm{K}$ antagonists in the treatment of acute symptomatic venous thromboembolism: a systematic review and meta-analysis. J. Thromb. Haemost. 2014; 12: 320-328.

9. Weitz J.I., Jaffer I.H. Optimizing the safety of treatment for venous thromboembolism in the era of direct oral anticoagulants. Pol. Arch. Med. Wewn. 2016; 126: 1-8.

10. Marlu R., Hodaj E., Paris A. i wsp. Effect of non-specific reversal agents on anticoagulant activity of dabigatran and rivaroxaban. A randomized crossover ex vivo study in healthy volunteers. Thromb. Haemost. 2012; 108: 217-224.

11. Pollack C.V. Jr, Reilly P.A., Eikelboom J. i wsp. Idarucizumab for dabigatran reversal. N. Engl. J. Med. 2015; 373: 511-520.

12. Glund S., Moschetti V., Norris S. i wsp. A randomised study in healthy volunteers to investigate the safety, tolerability and pharmacokinetics of idarucizumab, a specific antidote to dabigatran. Thromb. Haemost. 2015; 113: 943-951.

13. Glund S., Stangier J., Schmohl M. i wsp. Safety, tolerability, and efficacy of idarucizumab for the reversal of the anticoagulant effect of dabigatran in healthy male volunteers: a randomised, placebo-controlled, double-blind phase 1 trial. Lancet 2015; 386: 680-690.

14. Siegal D.M., Curnutte J.T., Connolly S.J. i wsp. Andexanet alfa for the reversal of factor Xa inhibitor activity. N. Engl. J. Med. 2015; 373: 2471-2472.

15. Connors J.M. Antidote for factor Xa anticoagulant. N. Engl. J. Med. 2015; 373: 2413-2424.

16. Ansell J.E., Bakhru S.H., Laulicht B.E. i wsp. Use of PER977 to reverse the anticoagulant effect of edoxaban. N. Engl. J. Med. 2014; 371: 2141-2142.

17. Khorana A.A. Venous thromboembolism and prognosis in cancer. Thromb. Res. 2010; 125: 490-493.

18. Khorana A.A. Cancer-associated thrombosis: updates and controversies. Hematology Am. Soc. Hematol. Educ. Program 2012; 626-630.

19. Farge D., Debourdeau P., Beckers M. i wsp. International clinical practice guidelines for the treatment and prophylaxis of venous thromboembolism in patients with cancer. J. Thromb. Haemost. 2013; 11: 56-70.

20. Khorana A.A., Carrier M., Garcia D.A., Lee A.Y.Y. Guidance for the prevention and treatment of cancer-associated venous thromboembolism. Thromb. Thrombolysis 2016; 41: 81-91.

21. Zawilska K. Profilaktyka i leczenie żylnych powikłań zakrzepowo-zatorowych u pacjentów z chorobą nowotworową. Hematologia 2014; 5: 228-238.

22. Wojtukiewicz M., Sierko E., Tomkowski W. i wsp. Guidelines for the prevention and treatment of venous thromboembolism in patients with cancers treated conservatively. Onkologia Clin. Pract. 2016; 12: 67-91.

23. Vedovati M-C., Germini F., Agnelli G., Becattini C. Direct oral anticoagulants in patients with VTE and cancer. A systematic review and meta-analysis. Chest 2015; 147: 475-483.

24. Lee A.Y., Levine M.N., Baker R.I. i wsp. Randomized comparison of low-molecular-weight heparin versus oral anticoagulant therapy for the prevention of recurrent venous thromboembolism in patients with cancer (CLOT) Investigators. Low-molecular-weight heparin versus a coumarin for the prevention of recurrent venous thromboembolism in patients with cancer. N. Engl. J. Med. 2003; 349: 146-153.

25. Lee A.Y., Kamphuisen P.W., Meyer G. i wsp.; for the CATCH Investigators. Tinzaparin vs warfarin for treatment of acute venous 


\section{Hematologia 2016, tom 7, nr 3}

thromboembolism in patients with active cancer. A randomized clinical trial. JAMA 2015; 314: 677-686.

26. Short N.J., Connors J.M. New oral anticoagulants and the cancer patient. Oncologist 2014; 19: 82-93.

27. O'Connell C., Razavi P., Ghalichi M. i wsp. Unsuspected pulmonary emboli adversely impact survival in patients with cancer undergoing routine staging multi-row detector computed tomography scanning. J. Thromb. Haemost. 2011; 9: 305-311.

28. Murchison J.T, Wylie L., Stockton D.L. Excess risk of cancer in patients with primary venous thromboembolism: a national, population-based cohort study. Br. J. Cancer 2004; 91: 92-95.

29. Watson H.G., Keeling D.M., Laffan M. i wsp. on behalf of the British Committee for Standards in Haematology. Guideline on aspects of cancer-related venous thrombosis. Brit. J. Haematol. 2015; 170: 640-648.

30. Enden T., Haig Y., Kløw N.E. i wsp.; CaVenT Study Group. Long-term outcome after additional catheter-directed thrombolysis versus standard treatment for acute iliofemoral deep vein thrombosis (the CaVenT study): a randomised controlled trial. Lancet 2012; 379: 31-38.

31. Meissner M.H., Gloviczki P., Comerota A.J. i wsp.; Society for Vascular Surgery Surgery, American Venous Forum. Early thrombus removal strategies for acute deep venous thrombosis: clinical practice guidelines of the Society for Vascular Surgery and the American Venous Forum. J. Vasc. Surg. 2012; 55:1449-1462.
32. Kahn S.R., Comerota A.J., Cushman M. i wsp.; American Heart Association Council on Peripheral Vascular Disease, Council on Clinical Cardiology, and Council on Cardiovascular and Stroke Nursing. The postthrombotic syndrome: evidence-based prevention, diagnosis, and treatment strategies: a scientific statement from the American Heart Association. Circulation 2014; 130: 1636-1661.

33. Ageno W., Beyer-Westendorf J., Garcia D. i wsp. Anticoagulation Forum. Guidance for the management of venous thrombosis in unusual sites. J. Thromb. Thromb. 2016; 41: 129-143.

34. Konstantinides S., Torbicki A., Agnelli G. i wsp. 2014 ESC Guidelines on the diagnosis and management of acute pulmonary embolism. The Task Force for the Diagnosis and Management of Acute Pulmonary Embolism of the European Society of Cardiology (ESC) Endorsed by the European Respiratory Society (ERS). Eur. Heart J. 2014; 35: 3033-3080.

35. Brighton T.A., Eikelboom J.W., Mann K. i wsp.; ASPIRE Investigators. Low-dose aspirin for preventing recurrent venous thromboembolism. N. Engl. J. Med. 2012; 367: 1979-87.

36. Andreozzi G.M., Bignamini A.A., Davi G. i wsp. The Sulodexide in secondary prevention of recurrent deep vein thrombosis (SURVET) study: a multicenter, randomized, double-blind, placebo-controlled trial. Circulation 2015; 132: 1891-1897.

37. Kyrle P.A. How I treat recurrent deep-vein thrombosis. Blood 2016; 127: 696-702. 